\title{
Determination of Antibacterial and Wound Healing Potentials of Ethanolic Extract of Cydonia oblonga Miller Fruit Venus Dilshad Najeeb (MSc) ${ }^{1}$, Sazan Moffaq Abdulaziz $(\mathrm{MSc}, \mathrm{PhD})^{2}$ and Prshng Tofiq Kurtas (MSc) ${ }^{3}$
}

\section{Abstract}

Background: Cydonia oblonga Miller (Quince) is one of the oldest cultural plants that belongs to the Rosaceae family. The bioactive components of Quince fruit are thought to have antimicrobial properties and able to accelerate the process of wound healing. The active ingredients that have antibacterial activity such as polyphenols can overcome the resistant mechanisms of bacteria and enhance killing through disturbing their metabolic activities.

Objective: To determination of antibacterial and wound healing potentials of ethanolic extract of Cydonia oblonga Miller Fruit.

Patients and Methods: The extract was prepared using hydroalcoholic extraction of quince whole fruit. Predominant wound bacteria isolates were obtained from active wounds on oral cheek mucosa of Albino Rabbits in a pilot study in which swab samples were taken from the induced oral wounds on the $2^{\text {nd }}$ day and immediately sent to the lab. The specimens were cultured on bacteriological media under aerobic and $\mathrm{CO}_{2}$ conditions at $37^{\circ} \mathrm{C}$ for $24 \mathrm{hr}$. discrete colonies were identified using microscopy, cultural characteristics and biochemical examinations. Different concentrations of the extract $(15,30,60,90$ and $120 \mathrm{mg} / \mathrm{ml})$ using well-diffusion agar method were tested for their antibacterial activity. In another pilot study, the effective extract concentration on wound healing was determined after 3, 5, 7 days post wounding. The extract concentration showed the best healing activity was used later and compared with normal healing (without treatment) and chlorhexidine-treated wounds. Histological assessment were used to judge on healing activity.

Results: Twelve bacterial isolates belonging to Neisseria sp., Staphylococcus aureus, Pseudomonas aeruginosa and Escherichia coli were tested. On the whole, all the isolates showed sensitivity to quince extract especially at high extract concentrations. Quince extract $60 \mathrm{mg} / \mathrm{ml}$ oral irrigation showed significant antibacterial effect following 3 days post wounding as no bacterial colonies were detected in the test group when compared with the negative and positive control groups with sever inflammatory infiltrate in all groups. Nearly, complete healing of the wounds after 5 and 7 days was recorded in all groups.

Conclusion: Cydonia oblonga Miller fruit ethanolic extract could be regarded as a good antibacterial substance with broad spectrum activity that promotes wound healing as well. The best concentration for both was $60 \mathrm{mg} / \mathrm{ml}$.

Keywords: Cydonia oblonga Miller, Antibacterial, Wound healing, Ethanolic extract. Corresponding Author: Venus.dilshad@ @mu.edu.krd 
Received: $15^{\text {th }}$ September 2019

Accepted: $2^{\text {nd }}$ October 2019

DOI:https://doi.org/10.26505/DJM.18014930915

1,2,3 Department of Basic science - Dentistry collage-Hawler Medical University -Irbil-Iraq

\section{Introduction}

Damage to oral soft tissue provides a suitable environment for the growth of microbes. It is one of the most common problems usually generated either as a complication of plaque accumulation such as gingivitis and periodontitis or due to surgery. Recovery from injury is determined by a number of factors such as location and size of the wound, immune status and oral hygiene[1].

Wound healing is a natural intricate process that includes a series of events achieved by a number of cells and inflammatory mediators[2]. Increased number of polymorphs and macrophages is the sign of active inflammatory process that has an important role in eliminating the invading microorganisms. A few days after injury, there is a decrease in the number of inflammatory cells and an increase in the number of fibroblasts. The latter cells are critical in the healing process as they promote synthesizing of collagen fiber, creating new extracellular matrix and contracting the wound as well. The whole process is controlled by different inflammatory mediators (growth factors, cytokines, proteases, kinins, and others) released by these cells and other cells at the site of injury. However, inflammation may be extended when microbial clearance is incomplete. Bacteria and their products can result in prolonged elevation of inflammatory cytokines such as TNF- $\alpha$ and interleukin-1. As a consequence, the wound may enter a chronic state and fail to recover[3]. Probably, wound infection is caused by multiple bacterial genera and/or species in the form of biofilms. The latter usually shows increased resistance rate to antibiotic treatment[4]. In the sense of increased antibiotic resistance among pathogenic bacteria due to improper use of antimicrobial drugs in addition to undesirable side effects[5], the focus has been changed toward traditional or herbal medicine for the treatment of various infectious diseases. Relatively, low rate side effects, availability and the diversity in the biologically active compounds of medicinal plants are the critical reasons behind their increased acceptance. Cydonia oblonga Miller (Quince) is one of the oldest cultural plants that belong to the Rosaceae family. It was originated from Central Asia and gradually spread to other parts of the world. However, it is less popular throughout the world when compared with other plant species. It has been recognized as an important nutritional source and traditionally used by many ancient cultures to treat various diseases[6]. Chemically, Quince fruit contains polyphenolic compounds, phenolic derivatives, flavonoids, and pectin that exhibit health promoting properties including 
antibacterial, anti-inflammatory, anticancer ,anti-bacteria and cardioprotective properties[7]. The aim was to evaluate the antibacterial potential of Quince fruit ethanolic extract against the most predominant wound bacterial isolates and to determine the healing potential of the extract on the experimentally induced oral wounds in rabbits' cheek mucosa.

\section{Patients and Methods}

Collection, preparation and extraction of plant material:Fresh quince fruit was purchased from local markets in Erbil City, Iraq. Using a sterilized knife, the fruit was sliced into small pieces and air-dried at room temperature. Then the dried material was grounded into fine powder using an electric blender (Panasonic MJ-M176P, Malaysia). The Hydroalcoholic method was used for extraction of Cydonia oblonga fruit[8]. Briefly, 50g of the prepared powder material was soaked in $500 \mathrm{ml}$ of ethanol solution (70\%) and left for 7 days in dark. Next, the solution was filtered through filter paper. Later, the extract was dried at $40^{\circ} \mathrm{C}$ and stored at $4{ }^{\circ} \mathrm{C}$ until used. Different concentrations $\quad(15 \mathrm{mg} / \mathrm{ml}, \quad 30 \mathrm{mg} / \mathrm{ml}$, $60 \mathrm{mg} / \mathrm{ml}, 90 \mathrm{mg} / \mathrm{ml}$, and $120 \mathrm{mg} / \mathrm{ml}$ ) were prepared in deionized water and tested for their antibacterial and wound healing properties[9].

\section{Induction of oral wound in rabbits}

A total of 30 male rabbits $(0.8-1.00 \mathrm{~kg})$ were included in the experiment. The animals were first adapted to the laboratory conditions for one week prior to the experimental work and housed in stainless steel cages at $12 \mathrm{hr}$ cycles of light and dark. Room temperature was kept at $24^{\circ} \mathrm{C}$. Standard food, vegetables and water were provided[10]. All animals used in this study were subjected to the same procedure, in which they were first received anesthesia (ketamine $60 \mathrm{mg} / \mathrm{kg} / \mathrm{xylazine}$ hydrochloride $7.5 \mathrm{mg} / \mathrm{kg}$ ) as intramuscular injections[11]. Then, an oral ulcer was made in each animal in the right buccal mucosa by the application of the punch biopsy[12]. The research project was approved by Scientific Committee at the college of dentistry /Hawler Medical University.

\section{Pilot study I}

The aim of this pilot study was to obtain the bacterial isolates that naturally colonize oral wound and used later in testing the antibacterial activity of quince extract. Six rabbits were included in which swab samples were taken from the induced oral wounds on the $2^{\text {nd }}$ day and immediately sent to the lab. The specimens were cultured on bacteriological media (blood agar, chocolate agar, and macConkey agar) under aerobic and $\mathrm{CO}_{2}$ conditions at $37^{\circ} \mathrm{C}$ for $24 \mathrm{hr}$. Discrete colonies were identified using microscopy, cultural characteristics and biochemical examinations (API 20 Strip)[13]. The most predominant bacterial isolates obtained from this study were Neisseria sp. Staphylococcus aureus, Escherichia coli and Pseudomonas aeruginosa.

\section{Assessment of antibacterial activity}

The agar well diffusion method was applied. Using a sterile swab, 0.5 McFarland 
$\left(10^{5} \mathrm{CFU} / \mathrm{ml}\right)$ dilution was prepared from overnight culture of each isolate obtained from Pilot study I. Then the inoculum was swabbed over the surface of appropriate agar plates (Muller Hinton agar and Muller Hinton blood agar). Wells of $6 \mathrm{~mm}$ of diameter were punched into the agar medium and filled with $80 \mu \mathrm{l}$ of different concentrations of plant extract $\quad(15 \mathrm{mg} / \mathrm{ml}, \quad 30 \mathrm{mg} / \mathrm{ml}, \quad 60 \mathrm{mg} / \mathrm{ml}$, $90 \mathrm{mg} / \mathrm{ml}$, and $120 \mathrm{mg} / \mathrm{ml}$ ) and chlorhexidine solution $(0.12 \%)$ that served as a positive control. Following incubation at $37^{\circ} \mathrm{C}$ for 18 $24 \mathrm{hr}$, the antimicrobial efficacy was evaluated by measuring the zone of growth inhibition. The mean of duplicate results were recoded[14]. Antimicrobial activity was decided on the basis of diameter of the inhibition zone as following: less than $10 \mathrm{~mm}$; no antimicrobial activity, $10-15 \mathrm{~mm}$; weak antimicrobial activity, $16-20 \mathrm{~mm}$; moderate antimicrobial activity, more than $20 \mathrm{~mm}$; high antimicrobial activity[9].

\section{Pilot study II}

This study was conducted to determine the most effective concentration of the plant extract in wound healing to be used later in the evaluation of the extract compared with normal healing (without treatment) and treatment based using $0.12 \%$ chlorhexidine solution. Six rabbits were included. According to the results of antimicrobial assessment, three concentrations of Quince extract were selected; $30 \mathrm{mg} / \mathrm{ml}, 60 \mathrm{mg} / \mathrm{ml}$, $90 \mathrm{mg} / \mathrm{ml}$ to treat induced oral ulcers. Specimens were taken on the third day of treatment, fixed in $10 \%$ formalin solution and send to the lab for histopathological processing and assessment. Following analysis it was shown that $60 \mathrm{mg} / \mathrm{ml}$ was the best concentration of Quince fruit extract to be used in the assessment.

\section{Assessment of wound healing activity}

Eighteen rabbits were used to evaluate the potential of Quince fruit extract $(60 \mathrm{mg} / \mathrm{ml})$ in wound healing in comparison to healing without any treatment and healing with the use of chlorhexidine solution (0.12\%). Animals were randomly divided into three groups, six rabbits in each:

Group 1: negative control (received no treatment)

Group 2: positive control (treated with chloroxidine solution $0.12 \%$ )

Group 3: test group (treated with ethanolic extract of Quince fruit $(60 \mathrm{mg} / \mathrm{ml}))$

Following the induction of oral wounds, animals of the second and third groups received their corresponding treatments by irrigating the wound with $1 \mathrm{ml}$ of freshly prepared solutions twice daily for 7 days using disposable syringes [15]. Specimens were collected on third, fifth and seventh days of wounding. Animals were sacrificed to collect wound samples for histopathological examination[16].

Histopathological processing and assessment

The obtained specimens from all animals were immediately placed in $10 \%$ formalin and sent to the lab for processing. The process included imbedding of specimens into paraffin blocks, sectioning, dewaxing and staining with hematoxylin and eosin. The stained tissue samples were examined under 
high power field (HPF400x) and the grade of inflammation, fibroblast counts, and wound size (The scores for wound size were characterized according to the width and depth of inflamed tissue) were evaluated in a semi-quantitative man $\neg$ ner Table (1)[2]. The means of all measurement were determined for each specimen. The evaluation was done by two pathologists.

Table (1): Histopathological measurements and wound scoring

\begin{tabular}{|c||l||c|c||}
\hline \hline \multicolumn{1}{|c||}{ Score } & \multicolumn{1}{|c|}{ Inflammation } & \multicolumn{1}{c||}{ Fibroblast } & Wound size \\
\hline \hline 0 & No acute inflammation & Absence of fibroblasts & Closed wound \\
\hline \hline 1 & $\begin{array}{l}\text { Mild inflammation (sub-mucosal } \\
\text { scattered inflammatory cells) }\end{array}$ & few fibroblasts & Small wound \\
\hline \hline 2 & $\begin{array}{l}\text { Moderate inflammation (Sub- } \\
\text { mucosal band-like inflammatory } \\
\text { infiltrate) }\end{array}$ & $\begin{array}{c}\text { Presence of disorganized } \\
\text { fibroblasts }\end{array}$ & Medium wound \\
\hline \hline 3 & $\begin{array}{l}\text { Severe inflammation (Sub-mucosal } \\
\text { diffuse inflammatory infiltrate) }\end{array}$ & $\begin{array}{c}\text { Presence of fibroblasts } \\
\text { parallel to wound surface }\end{array}$ & Large wound \\
\hline
\end{tabular}

\section{Statistical analysis}

Data were expressed as mean \pm SD. Data analysis was done by ANOVA and the comparison between groups was done by Sidack test using GraphPad Prism 7.0. The significance level was set at $\mathrm{P}<0.05$.

\section{Results}

\section{Assessment of antibacterial activity}

The results of the in vitro antibacterial efficacy of ethanolic extract of Cydonia oblonga Miller are presented in Table(2). Twelve bacterial isolates belonging to 4 bacterial genera, Neisseria sp., Staphylococcus aureus, Pseudomonas aeruginosa and Escherichia coli (E. coli) were tested for their sensitivity to five different concentrations of the extract; $15 \mathrm{mg} / \mathrm{ml}, 30 \mathrm{mg} / \mathrm{ml}, 60 \mathrm{mg} / \mathrm{ml}, 90 \mathrm{mg} / \mathrm{ml}$, and $120 \mathrm{mg} / \mathrm{ml}$. On the whole, all the isolates showed sensitivity to quince extract, but there was variation in their sensitivity in respect to extract concentration even within the same species. The same results showed that both Gram negative and Gram positive bacteria displayed sensitivity to quince extract ranged from statistically nonsignificant to very highly significant when compared to their sensitivity to $0.12 \%$ chlorhexidine solution. Isolates of Staphylococcus aureus, Pseudomonas aeruginosa and E. coli showed better sensitivity than isolates belonging to Neisseria sp. Table (3) presents the overall sensitivity of each genus to different concentrations of Quince extract. An increase in the antibacterial activity was recorded with increasing extract concentration. Extract concentration of $60 \mathrm{mg} / \mathrm{ml}$ showed the best activity among all the tested concentrations. 
Determination of Antibacterial and Wound Healing Potentials of Ethanolic Extract of Cydonia oblonga Miller Fruit

Table (2): Antibacterial activity of ethanolic extract of Cydonia oblonga Miller (Inhibition zones in $\mathrm{mm} \pm \mathrm{SD})$

\begin{tabular}{|c|c|c|c|c|c|c|}
\hline \multirow[t]{2}{*}{ Bacterial strain } & \multirow{2}{*}{$\begin{array}{c}\text { Chlorhexidine } \\
(0.12 \%)\end{array}$} & \multicolumn{5}{|c|}{ Quince extract $(\mathrm{mg} / \mathrm{ml})$} \\
\hline & & $\overline{c 15}$ & 30 & $\overline{c 60}$ & 90 & 120 \\
\hline "Neisseria sp. 1 & $20 \pm 2$ & 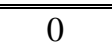 & $12 \pm 1$ & $\overline{10 \pm 1}$ & $\bar{~} 17 \pm 1$ & $18 \pm 1$ \\
\hline Neisseria sp. 2 & $20 \pm 2.1$ & 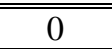 & $16 \pm 1.2$ & $19 \pm 1.2$ & $15 \pm 1.2$ & $16 \pm 1.2$ \\
\hline Neisseria sp. 3 & $15 \pm 1.2$ & 0 & 0 & 0 & $14 \pm 0$ & $15 \pm 0$ \\
\hline S. aureus 1 & $24 \pm 0.3$ & $10 \pm 1$ & $20 \pm 2$ & $27 \pm 0.5 * *$ & $15 \pm 2$ & $15 \pm 2$ \\
\hline S. aureus 2 & $28 \pm 3$ & 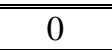 & $10 \pm 1$ & $\overline{15 \pm 1}$ & $\overline{13 \pm 1}$ & $\overline{14 \pm 1}$ \\
\hline S. areus 3 & $25 \pm 3.1$ & $\overline{10 \pm 1}$ & $\overline{15 \pm 2}$ & $20 \pm 2$ & $\overline{19 \pm 2}$ & $20 \pm 2$ \\
\hline P. aeruginosa & $25 \pm 2.3$ & 0 & $32 \pm 2 * * *$ & $35 \pm 2 * * *$ & $11 \pm 2$ & $13 \pm 2$ \\
\hline E. coli 1 & $22 \pm 2.2$ & $\overline{0}$ & $17 \pm 1$ & $18 \pm 1$ & $23 \pm 1$ & $24 \pm 1 *$ \\
\hline E. coli 2 & $20 \pm 2$ & $16 \pm 1.2$ & $16 \pm 2$ & $21 \pm 2$ & $30 \pm 2 * * *$ & $32 \pm 2 * * *$ \\
\hline E. coli 3 & $18 \pm 2$ & 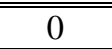 & $10 \pm 1$ & $17 \pm 1$ & $15 \pm 1$ & $15 \pm 1$ \\
\hline E. coli 4 & $20 \pm 2$ & 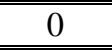 & $10 \pm 1$ & $15 \pm 1$ & $18 \pm 1$ & $20 \pm 1$ \\
\hline E. coli 5 & $13 \pm 1.2$ & 0 & $15 \pm 2$ & $17 \pm 2 * *$ & $\overline{15 \pm 2}$ & $16 \pm 2 * *$ \\
\hline
\end{tabular}

Table (3): Range of antibacterial activity of ethanolic extract of Cydonia oblonga Miller

\begin{tabular}{|c|c|c|c|c|c|c|c|}
\hline \multirow{2}{*}{$\begin{array}{c}\text { Antibacterial } \\
\text { activity }\end{array}$} & \multirow[t]{2}{*}{ Bacterial strain } & \multicolumn{5}{|c|}{ Quince extract $(\mathrm{mg} / \mathrm{ml})$} & \multirow[t]{2}{*}{ Tota } \\
\hline & & $1 \overline{15}$ & 30 & 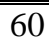 & $\overline{90}$ & 120 & \\
\hline \multirow{4}{*}{$\begin{array}{c}\text { No } \\
\text { Activity }\end{array}$} & Neisseria $\mathrm{sp}$. & $\begin{array}{c}3 \\
\end{array}$ & 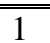 & $\overline{c 1}$ & $\overline{0}$ & $\overline{c 0}$ & \multirow[t]{4}{*}{11} \\
\hline & S. aureus & 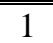 & $\overline{00}$ & $\overline{00}$ & $\bar{~} 0$ & $\overline{00}$ & \\
\hline & Pseudomonas sp. & 1 & 0 & 0 & 0 & 0 & \\
\hline & E. coli & 4 & 0 & 0 & 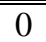 & 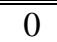 & \\
\hline \multirow[t]{4}{*}{ Weak activity } & Neisseria sp. & 0 & 1 & 0 & 2 & 1 & \multirow[t]{4}{*}{22} \\
\hline & S. aureus & $\overline{22}$ & $\overline{2} 2$ & $\begin{array}{ll}1 \\
\end{array}$ & 2 & 2 & \\
\hline & P. aeruginosa & 0 & 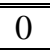 & 0 & 1 & $\overline{1}$ & \\
\hline & E. coli & 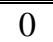 & 3 & 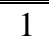 & 2 & $\overline{11}$ & \\
\hline \multirow{4}{*}{$\begin{array}{c}\text { Moderate } \\
\text { activity }\end{array}$} & Neisseria sp. & 0 & 1 & 2 & 1 & 2 & \multirow[t]{4}{*}{19} \\
\hline & S. aureus & 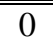 & 1 & 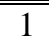 & 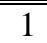 & 1 & \\
\hline & Pseudomonas sp. & 0 & 0 & 0 & 0 & 0 & \\
\hline & E. coli & 1 & 2 & 3 & 1 & 2 & \\
\hline \multirow{4}{*}{$\begin{array}{c}\text { High } \\
\text { Activity }\end{array}$} & Neisseria $\mathrm{sp}$. & 0 & 0 & 0 & $\overline{0}$ & $\overline{0}$ & \multirow[t]{4}{*}{8} \\
\hline & S. aureus & 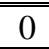 & 0 & 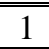 & $\overline{0}$ & $\overline{0}$ & \\
\hline & Pseudomonas sp. & 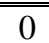 & 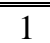 & $\begin{array}{l}1 \\
\end{array}$ & $\overline{0}$ & 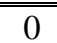 & \\
\hline & E. coli & 0 & 0 & 1 & 2 & 2 & \\
\hline
\end{tabular}

Inhibition zones were classified as: no antimicrobial activity $(<10 \mathrm{~mm})$, weak activity $(10-15 \mathrm{~mm})$, moderate activity $(16-20 \mathrm{~mm})$ and high activity $(>20 \mathrm{~mm})$.

S. aureus: Staphylococcus aureus, P. aeruginosa: Pseudomonas aeruginosa, E. coli: Escherichia coli. 


\section{Assessment of wound healing activity}

The histological assessment of wound healing activity of Quince fruit extract showed that following 3 days post wounding in the treated (treated with ethanolic extract of Quince fruit $(60 \mathrm{mg} / \mathrm{ml}))$ group the wound size was $3 \mathrm{~mm}$ in diameter and ulcer base consists of sever acute inflammatory cells mainly neutrophil infiltrate about 40 to 50 cells in high power field examination with vascular extension of coagulation. The roof consists of fibro-purulent exudate. No bacterial colonies were observed! The same assessment in negative control (received no treatment) group showed that the wound size was $3.5 \mathrm{~mm}$ in diameter and ulcer covered by necrotic debris and bacterial colonies specially cocci with neutrophils infiltrate about 40 to 50 cells and lymphocytes 5-10 cells with granulation tissue formation at the ulcer base. In the positive control (treated with chloroxidine solution $0.12 \%$ ) group ulcer size was $3.0 \mathrm{~mm}$ in diameter also covered by necrotic debris and scattered bacterial colonies. Severe diffuse inflammatory infiltrate, neutrophils (30-40 cells) and lymphocytes (1-5 cells) were seen. Ulcer was extended to muscular layer and granulation tissue was formed at the ulcer base as shown in Figure (1). Complete healing of the wound after 5 days post wounding in all groups was recorded. However, in negative control there were presence of mild submucosal scattered inflammatory cells, mononuclear infiltrate (1-5) and Fibroblasts arranged in different directions to the wound surface. In the test and positive control groups fibroblasts were parallel to the wound surface Figure (2). Complete healing of the wound after 7 days post wounding was recorded in all groups. Fibroblasts parallel to the wound surface in both the test and positive control groups were also recoded, meanwhile in the negative control there was mild mononuclear inflammatory cells infiltrate (1-5) Figure (3).

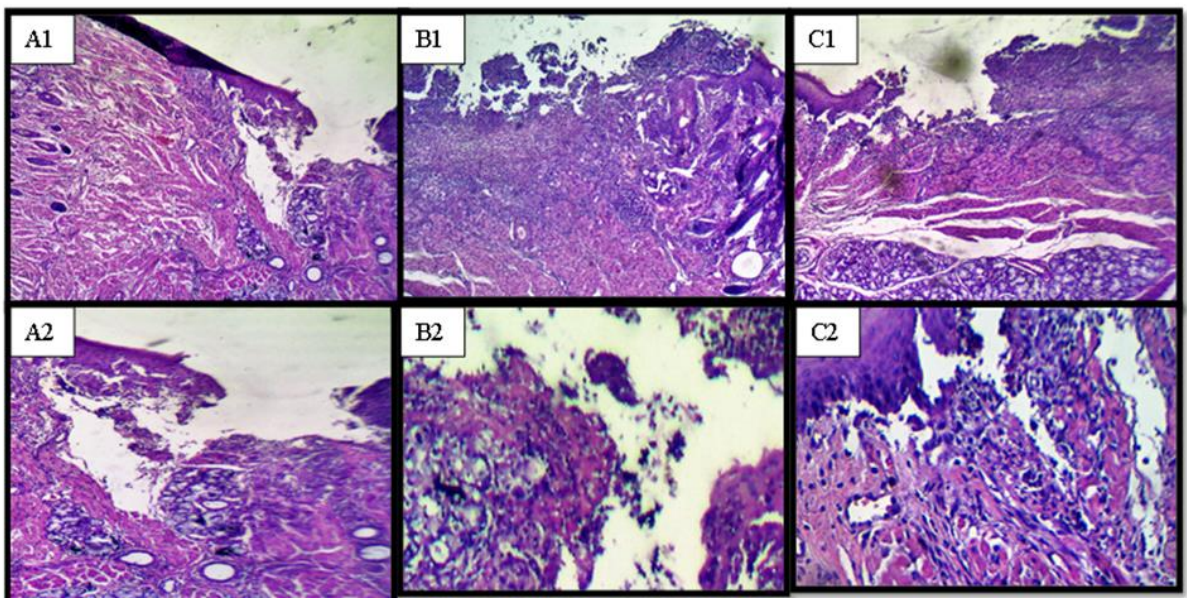

Figure (1): Histological sections of right buccal mucosa after 3 days post wounding using low power (40X) (1) and high power (400X) (2). A1 and A2 test group, B1 and B2 negative control group, C1 
andC2 positive control group

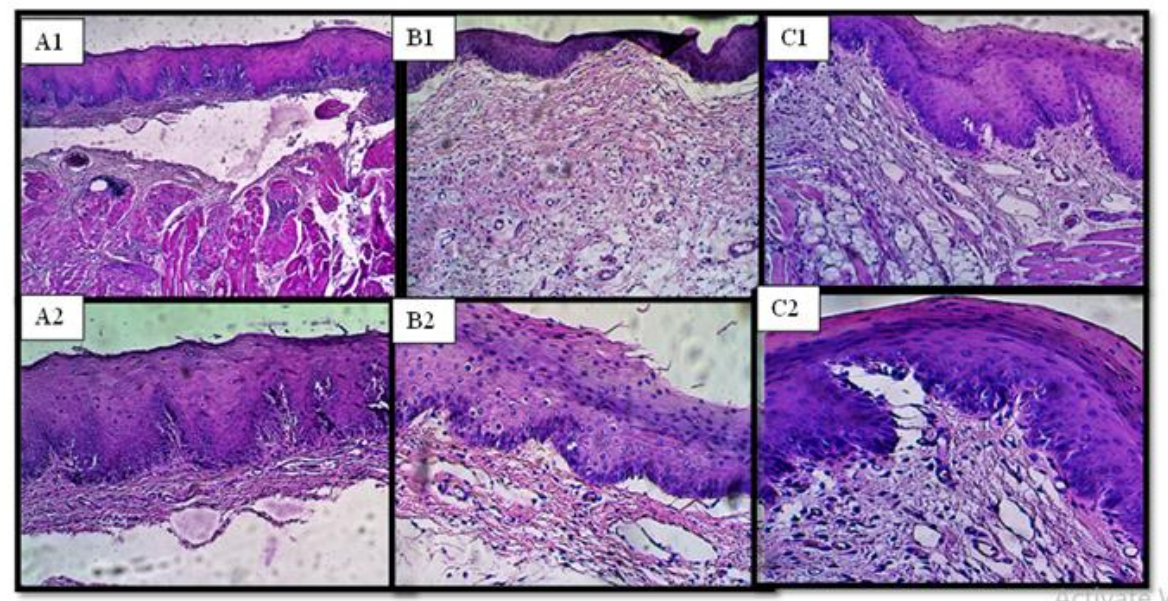

Figure (2): Histological sections of right baccal mucosa after 5 day post wounding using low power (40X) (1) and high power (400X) (2). A1 and A2 test group, B1 and B2 negative control group, C1 andC2 positive control group

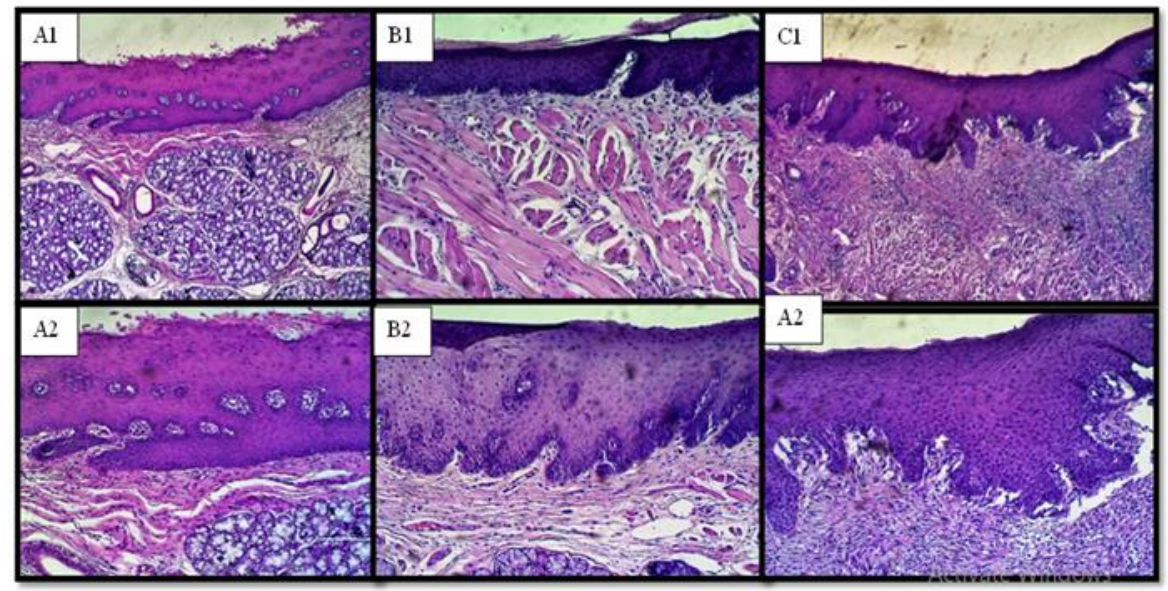

Figure (3): Histological sections of right baccal mucosa after 7 day post wounding using low power (40X) (1) and high power (400X) (2). A1 and A2 test group, B1 and B2 negative control group, C1 andC2 positive control group

\section{Discussion}

This study has been conducted to determine both antibacterial and wound healing potentials of Cydonia oblonga Miller fruit ethanolic extract. Overall, the prepared extract showed good dual activity. It was found that higher extract yields, phenolic contents and antioxidant activity obtained using aqueous organic solvents[17]. Quince fruit ethanolic extract showed a good activity against the tested strains of Gram negative and Gram positive bacteria and both groups displayed nearly similar range of sensitivity to the extract. Isolates of Staphylococcus aureus, Pseudomonas aeruginosa and E. coli showed better sensitivity than isolates 
belonging to Neisseria sp. The same results also showed that the antibacterial activity increased with increasing extract concentration. The antibacterial activity of Quince fruit is attributed to the some chemical substances that have antimicrobial activity such as phenolic compounds[17]. Alizadeh et al. (2013) and Cerempei et al. (2016) have analysed the whole Quince fruit extract for phenolic contents and antimicrobial activity of the extract. Both studies have found that the fruit is enriched in different phenolic compounds and derivatives, but little in vitro antimicrobial activities against different groups of Gram positive and Gram negative bacteria have been recorded. In another study thirty-four polyphenols were detected in quince fruit extract and the antibacterial activity was observed against $E$. coli in high concentrations. The increase in antimicrobial activity with increasing concentration is attributed to the increase in active ingredients that has antibacterial activity in microbial environment that can overcome the resistant mechanisms of bacteria and disturb their metabolic activity[20].

The results showed that when quince extract $60 \mathrm{mg} / \mathrm{ml}$ oral irrigation used, following three days post wounding there was no bacterial colonies in the test group when compared with the negative (received no treatment) and positive control (treated with chloroxidine solution $0.12 \%$ ) groups with sever inflammatory infiltrate in all groups. The same results showed complete healing of the wounds after 5 and 7 days post wounding in all groups. However, a mild mononuclear inflammatory cells infiltrate was seen in the negative control group and this is definitely because this group received no treatment. The same results were reported by Parvan et al. (2017). Wound healing is a complex process and affected by a number of factors. For example, infection with bacteria and poor blood supply has negative impact on wound healing. Supplying the wound with certain vitamins and elements may facilitate healing. Vitamin $\mathrm{C}$ and zinc have positive impact on wound healing as they have antiinflammatory effect[18]. So, the presence of any chemical may affect the process either by promoting or inhibiting. The absence of bacterial colonies in test group denoted for the potent in vivo antibacterial activity of quince extract that supports the in vitro results. Prolonged presence of bacteria in the wound usually causes a delay in healing as they enhance more inflammatory reactions and produce toxic products[19].

Chlohexidine promotes wound healing through its antimicrobial properties[20], whereas natural extracts are enriched in bioactive compounds that facilitate healing through multiple effects. For example, studies showed that quince fruit extract is enriched in tannins and phenolic compounds that induce healing of wounds and inflamed mucous membranes during the inflammatory phase through chelation of free radicals, enhancing wound contraction, formation of new capillary vessels and fibroblasts and keratinocytes proliferation in addition to their antibacterial activity [21],[22],[23],[24]. 


\section{Conclusions}

Cydonia oblonga Miller fruit ethanolic extract could be regarded as a good antibacterial substance with broad spectrum activity and promotes wound healing as well. The best concentration for both was $60 \mathrm{mg} / \mathrm{ml}$.

\section{References}

[1]Nagappan R. Evaluation of aqueous and ethanol extract of bioactive medicinal plant, Cassia didymobotrya (Fresenius) Irwin \& Barneby against immature stages of filarial vector, Culex quinquefasciatus Say (Diptera: Culicidae). Asian Pac J Trop Biomed 2012;2(9):707-11.

[2]Fonseca CME, Quirino MRS, Patrocinio MC, Anbinder AL. Effects of Chamomilla recutita (L.) on oral wound healing in rats. Med Oral Patol Oral Cir Bucal. 2011:e716e21.

[3]Broughton G, 2nd, Janis JE, Attinger CE. Wound healing: an overview. Plast Reconstr Surg. 2006;117(7 Suppl):1e-S-32e-S.

[4]Menke NB, Ward KR, Witten TM, Bonchev DG, Diegelmann RF. Impaired wound healing. Clin Dermatol. 2007;25(1):19-25.

[5]Davies J. Inactivation of Antibiotics and the Dissemination of Resistance Genes. SCIENCE 1994;264:378-82.

[6]Leonel M, Leonel S, Tecchio MA, Mischan MM, Moura MF, Xavier D. Characteristics of quince fruits cultivars' (Cydonia oblonga Mill.) grown in Brazil. AJCS. 2016;10(05):711-6.

[7]Cerempei A, Mureşan EI, Cimpoeşu N, Carp-Cărare C, Rimbu C. Dyeing and antibacterial properties of aqueous extracts from quince (Cydonia oblonga) leaves. Industrial Crops and Products. 2016;94:21625.

[8]Bussmann RW, Malca-Garcia G, Glenn A, Sharon D, Chait G, Diaz D, et al. Minimum inhibitory concentrations of medicinal plants used in Northern Peru as antibacterial remedies. $\mathbf{J} \quad$ Ethnopharmacol. 2010;132(1):101-8.

[9]Pirvu L, Hlevca C, Nicu I, Bubueanu C. Comparative studies on analytical, antioxidant, and antimicrobial activities of a series of vegetal extracts prepared from eight plant species growing in Romania. JPC. 2014;27(5):346-56.

[10]Tamri P, Hemmati A, Boroujerdnia MG. Wound healing properties of quince seed mucilage: in vivo evaluation in rabbit fullthickness wound model. Int $\mathbf{J}$ Surg. 2014;12(8):843-7.

[11] Torabi M, Aminizadeh M, Karimiafshar H, Asadi M, Afzali M. Study on the Effect of Essence and Extract of Thymus caramanicus Jalas on the Process of Oral Wound Healing in Rats. ajbps. 2015;5(44):1-5.

[12]Deyhimi $\mathrm{P}$, Khademi $\mathrm{H}$, Birang $\mathrm{R}$, Akhoondzadeh M. Histological Evaluation ofWound Healing Process after Photodynamic Therapy of Rat Oral Mucosal Ulcer. J Dent Shiraz Univ Med Sci. 2016;17(1): 43-8.

[13]Cheesbrough M. District Laboratory Practice in Tropical Countries. United States of America by Cambridge University Press, New York: CAMBRIDGE UNIVERSITY PRESS; 2005. 
[14]Ahmad I, Beg AZ. Antimicrobial and phytochemical studies on 45 Indian medicinal plants against multi-drug resistant human pathogens. Journal of Ethnopharmacology 2001;74:113-23. [15]Alsayed AZ, El-Bakry MH, Fahmy AA. Effect of Licorice on Wound Healing In Rabbits. The Egyptian J of Hosp Med. 2005;20:58-65.

[16]Omidian M, Hemmati AA, Farajzade H, Houshmand G, Sattari A, Kouchak M. Priority of 5\% Quince Seed Cream Versus $1 \%$ Phenytoin Cream in the Healing of Skin Ulcers: A Randomized Controlled Trial. Jundishapur J Nat Pharm Prod. 2015;10(2). [17]Alizadeh H, Rahnema M, Semnani SN, Hajizadeh N. Detection of Compounds and Antibacterial Effect of Quince (Cydonia oblongaMiller) Extractsin vitroandin vivo. TBAP 2013;3(5-6):303-9.

[18]Sabale P, Bhimani B, Prajapati C, Sabalea V. An overview of medicinal plants as wound healers. JAPS. 2012;2(11):143-50. [19]Hemmati AA, Kalantari H, Jalali A, Rezai S, Zadeh HH. Healing effect of quince seed mucilage on T-2 toxin-induced dermal toxicity in rabbit. Exp Toxicol Pathol. 2012;64(3):181-6.

[20]Charles CH, Mostler KM, Bartels LL, Mankodi SM. Comparative antiplaque and antigingivitis effectiveness of a chlorhexidine and an essential oil mouthrinse: 6-month clinical trial. J Clin Periodontol. 2004;31(10):878-84.

[21]FU E, CE O, GC U. Phytochemical and antimicrobial activity screening of Gnetum africanum leaf extracts. International Journal of Herbal Medicine. 2017;5(3): 105-9. [22] V. Ilodibi C, J. Ezeja I, E. Akachuk E, U. Chukwum M, P. Egboka T, N. Emeka A. Phytochemical Screening and Antimicrobial Effects of Aqueous and Ethanol Leaf and Stem Extracts of Gongronema latifolium Benth. Research Journal of Botany. 2015;10(2):50-60.

[23]Benzarti S, Hamdi H, Lahmayer I, Toumi W, Kerkeni A, Belkadhi K, et al. Total phenolic compounds and antioxidant potential of quince (Cydonia oblonga Miller) leaf methanol extract. ijias. 2015;13(3): 51826.

[24]T S, Ramadas V, Kishore SSS. Antimicrobial activity of selected medicinal plants against some selected human pathogenic bacteria. Adv Appl Sci Res. 2012;3(5):3374-81. 